\title{
Pengolahan Limbah Domestik Menggunakan Moving Bed Biofilm Reactor (MBBR) dengan Proses Aerobik-Anoksik untuk Menurunkan Nitrogen
}

\author{
Ana Anisa dan Welly Herumurti \\ Departemen Teknik Lingkungan, Fakultas Teknik Sipil dan Perencanaan, Institut Teknologi Sepuluh Nopember (ITS) \\ e-mail: anaanissa21@gmail.com
}

\begin{abstract}
Abstrak-Limbah domestik memiliki kandungan organik, ammonium, nitrat yang tinggi dan dapat menyebabkan pencemaran jika langsung dibuang ke badan air. Sehingga diperlukan pengolahan terhadap limbah agar memenuhi kualitas baku mutu yang berlaku. Salah satu pengolahan limbah adalah dengan melalui proses pengolahan biologis yang dilakukan dengan memanfaatkan mikroorganisme untuk mendegradasi polutan. Salah satu unit pengolahan secara biologis yang sudah umum digunakan adalah Moving Bed Biofilm Reactor (MBBR). Media biofilm yang digunakan dalam penelitian ini adalah media kaldness (K1). Dalam pelaksanaan penelitian ini, digunakan limbah yang berasal dari unit ABR Jurusan Teknik Lingkungan ITS dengan variasi konsentrasi COD sesuai dengan konsentrasi yang berasal dari inlet dan outlet unit ABR guna menguji kemampuan MBBR dalam mengolah limbah domestik dengan beban organik yang berbeda-beda. Variasi konsentrasi COD yang digunakan adalah konsentrasi low $(130$ - 170) $\mathrm{mg} / \mathrm{L}$; konsentrasi medium $(270$ - 310) $\mathrm{mg} / \mathrm{L}$ dan konsentarsi high $(370-460) \mathrm{mg} / \mathrm{L}$. Selama berlangsungnya penelitian, unit ini dijalankan dengan durasi proses aerobik-anoksik yang berbeda pada masingmasing reaktor dengan tujuan menentukan waktu durasi pengolahan aerobik dan anoksik yang paling optimal. Reaktor terbuat dari pipa PVC dengan volume pengolahan sebanyak 5 L. Parameter yang digunakan adalah COD, ammoniumnitrogen, nitrat-nitrogen, nitrit-nitrogen, BOD, pH, DO, MLSS, MLVSS. Berdasarkan hasil analisis terlihat bahwa MBBR dengan media kaldness mampu menurunkan kandungan organik sebesar $81,4 \%$; BOD sebesar 83,6\%; ammonium-nitrogen sebesar $92,8 \%$; nitrat-nitrogen sebesar 66,4\% dan nitrit-nitrogen sebesar $99,7 \%$. Selain itu, durasi pengolahan limbah dengan hasil optimum dicapai pada reaktor dengan durasi pengolahan aerobik selama 31,5 jam dan anoksik selama 13,5 jam.
\end{abstract}

Kata Kunci-amonium, COD, Limbah Domestik, Moving Bed Biofilm Reactor (MBBR), Nitrat.

\section{PENDAHULUAN}

P ERTUMBUHAN penduduk yang terus meningkat setiap tahun akan berbanding lurus dengan kegiatan manusia setiap harinya. Meningkatnya kegiatan manusia tersebut akan menyebabkan dampak positif dan dampak negative terhadap lingkungan. Salah satu dampak negatif yang ditimbulkan adalah bertambahnya jumlah limbah yang dihasilkan, dalam penelitian ini limbah yang akan menjadi bahan uji berupa limbah cair domestik. Limbah domestik cenderung memiliki kandungan senyawa organik dan nitrogen tinggi, yang apabila tidak di olah akan menyebabkan pencemaran terhadap badan air penerima [1]. Jenis nitrogen anorganik yang utama dalam air adalah nitratnitrogen $\left(\mathrm{NO}_{3}-\mathrm{N}\right)$, ammonium-nitrogen $\left(\mathrm{NH}_{3}-\mathrm{N}\right)$ dan nitrit- nitrogen $\left(\mathrm{NO}_{2}-\mathrm{N}\right)$. Nitrit merupakan bentuk peralihan dari ammonium menjadi nitrat yang disebut dengan nitrifikasi sedangkan peralihan dari bentuk nitrit menjadi gas nitrogen disebut denitrifikasi. Nitrifikasi berlangsung pada kondisi aerobik dan denitrifikasi berlangsung pada kondisi anoksik [2].

Konsentrasi senyawa nitrogen yang tinggi akan menyenbabkan masalah bagi badan air, salah satunya adalah dapat menurunkan kandungan Dissolved Oxygen, memicu terjadinya eutrofikasi dan meningkatkan kadar toksisitas suatu badan air [3]. Oleh karena itu perlunya pengolahan yang tepat terhadap limbah domestik sebelum dibuang kebadan air. Jenis pengolahan yang banyak dikembangkan adalah pengolahan secara biologis yaitu dengan memanfaatkan mikroorganisme untuk mendegradasi senyawa organik serta untuk menurunkan kandungan nitrogen didalam air limbah. Moving Bed Biofilm Reactor (MBBR) merupakan salah satu unit pengolahan biologis yang memanfaatkan biofilm yaitu dengan sistem fluidized attached growth (mikroorganisme yang tumbuh dan berkembangbiak pada media) [4]. Selama proses pengolahan berlangsung, MBBR memanfaatkan proses aerobik- anoksik yang berpotensi untuk menurunkan kandungan nitrogen melalui proses nitrifikasi dan denitrifikasi. Efisiensi removal nitrogen pada limbah domestik melalui proses aerobikanoksik mencapai 65-70\% [3]. Pada penelitian lain menambahkan bahwa efisiensi removal nitrogen dapat mencapai $80,9 \%$ dan khususnya pada ammonium mencapai 99,72\% pada limbah artifisial dengan konsentrasi COD 500 $\mathrm{mg} / \mathrm{L}$ [5]. Penurunan kandungan nitrogen yang terjadi dapat disebabkan oleh beberapa faktor, antara lain adalah beban organik limbah yang akan diolah dan waktu durasi pengolahan secara aerobik dan anoksik yang diterapkan. Untuk variasi durasi pengolahan aerobik-anoksik yang paling optimum belum diketahui, oleh karena itu, diperlukan penelitian mengenai pengolahan senyawa organik dan nitrogen secara bioloigs menggunakan reaktor MBBR.

\section{METODE PENELITIAN}

\section{A. Persiapan Alat dan Bahan}

Sebelum dilakukan penelitian laboratotium terlebih dahulu menyiapkan alat dan bahan yang dibutuhkan. Alat alat yang dibtuhkan untuk menunjang jalannya penelitian antara lain pipa PVC 4", aerator, pompa submersible, media kaldness (K1), glassware, kertas saring dan vacuum filter. Sedangkan bahan - bahan yang diperlukan antara lain limbah domestik yang diambil dari unit Anaerobic Baffle Reactor (ABR) Departemen Teknik Lingkungan-ITS, lumpur aktif yang berasal dari Return Activated Sludge 
(RAS) unit clarifier- IPLT keputih, reagen-reagen yang diperlukan untuk analisis sampel.

\section{B. Analisis Karakteristik Awal Limbah}

Analisis ini dilakukan untuk mengetahui seberapa besar konsentrasi senyawa organik pada limbah yang akan diolah sehingga ketika penelitian dilakukan dapat memudahkan dalam penentuan variasi konsentrasi yang digunakan. Parameter yang diuji dalam analisis awal ini adalah parameter yang digunakan sebagai parameter utama selama berjalannya penelitian, yaitu COD, amonium, nitrat dan nitrit.

\section{Seeding dan Aklimatisasi}

Seeding dilakukan dengan tujuan untuk memperbanyak populasi mikroorganisme dengan menambah lumpur aktif secara batch ke dalam reaktor yang telah diisi oleh media kaldness. Selama masa seeding, dilakukan penambahan gula sebanyak 1 sendok/hari ke dalam lumpur aktif selama 3 hari, lalu lumpur dikondisikan dengan MLSS sebesar $4000 \mathrm{mg} / \mathrm{L}$ dan dimasukan kedalam masing - masing reaktor. Kemudian dilakukan proses aklimatisasi yaitu dengan menambahkan limbah domestik dengan konsentrasi yang berbeda-beda sesuai dengan variasi uji yang dilakukan pada masing-masing reaktor. Volume lumpur yang dimasukan adalah sebanyak $1 \mathrm{~L}$ dan volume limbah yang ditambahkan adalah sebanyak 5 L [6]. Tujuan dilakukannya aklimatisasi adalah untuk mengadaptasikan mikroorganisme dengan kondisi lingkungan yang baru, termasuk sumber makanannya. Pertumbuhan bakteri ditandai dengan perubahan warna suspensi menjadi coklat kehitaman dan terjadi peningkatan nilai MLVSS [7]. Ketika lumpur aktif sudah mencapai kondisi steady state maka penelitian sudah bisa dimulai. Kondisi steady state yang dimaksud adalah keadaan dimana efisiensi removal COD tidak lebih dari 5\% dari efisiensi removal siklus sebelumnya.

\section{Pembuatan Reaktor}

Reaktor uji yang digunakan dalam penelitian ini adalah pipa PVC dengan diameter $\pm 10 \mathrm{~cm}$ dan tinggi $100 \mathrm{~cm}$. Volume pengolahan pada reaktor uji adalah sebanyak $5 \mathrm{~L}$. Konsentarsi MLSS yang dibutuhkan di dalamnya adalah sebesar $4000 \mathrm{mg} / \mathrm{L}$. Media yang digunakan adalah media kaldness (K1) (Gambar 1) karena media yang baik untuk digunakan dalam unit MBBR adalah media yang tipis dan pergerakan media yang merata. Pada masing - masing reaktor disambung kan dengan aerator yang akan dihidupkan pada saat kondisi aerobik berlangsung serta di dalamnya terdapat pompa submersible yang akan dinyalakan ketika durasi anoksik berlangsung (Gambar 2).

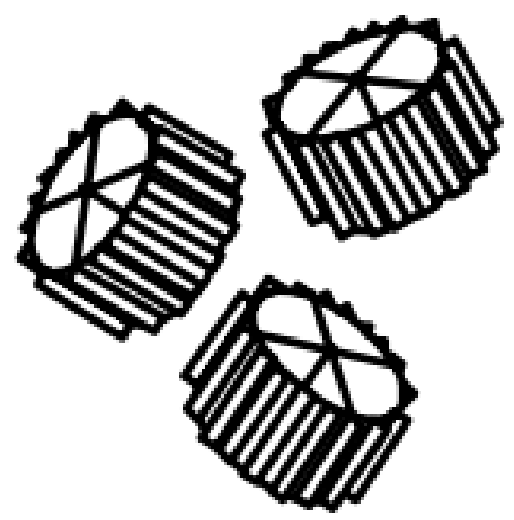

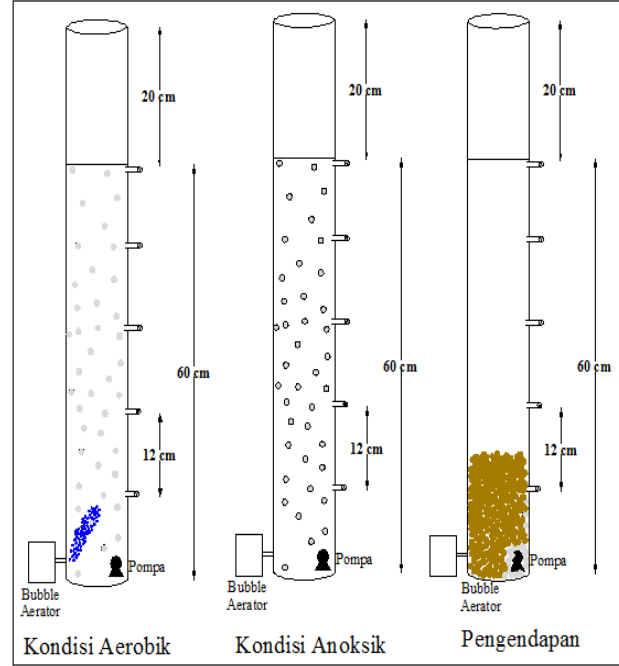

Gambar 2. Reaktor Uji.

\section{E. Pelaksanaan Penelitian}

Penelitian dilaksanakan selama \pm 54 hari. Selama analisis parameter utama dilakukan dalam 3 durasi waktu aerobik dan anoksik yang berbeda-beda. Pada running pertama dilakukan pengolahan dengan waktu durasi proses aerobik selama 31,5 jam-anoksik 13,5 jam; lalu pada running selanjutnya dilakukan pengolahan dengan waktu durasi aeorobik 22,5 jam-anoksik 22,5 jam dan terakhir adalah pengolahan dengan waktu durasi aerobik selama 13,5 jamanoksik 31,5 jam. Proses aerobik-anoksik tersebut dilakukan di dalam reaktor yang sama dan siklus tersebut dilakukuan berulang sampai pada siklus ketiga. Namun, dalam setiap kali running, tiga reaktor disiapkan dengan konsentrasi yang berbeda - beda yang sudah di tentukan sebelumya. Proses sampling untuk analisis COD dan nitrogen dilakukan pada influent awal, fase sebelum aerobik dan fase sebelum anoksik pada masing - masing siklus. Sedangkan untuk uji MLSS sampling dilakukan pada saat setelah proses pengendapan.

\section{F. Analisis Data dan Kesimpulan}

Pembahasan mengenai hubungan antar satu parameter dengan parameter lain dan sebab akibat hasil analisis yang diperoleh. Kesimpulan disusun berdasarkan analisis data penelitian serta permbahasan. Kesimpulan berisi jawaban atas rumusan masalah dan tujuan yang diharapkan dari adanya penelitian ini. Kesimpulan dibuat menggunakan poin - poin yang dibuat secara ringkas.

\section{HASIL DAN PEMBAHASAN}

\section{A. Hasil Analisis Karakteristik Awal limbah}

Analisis karakteristik awal ini bertujuan untuk mengetahu besar konsentrasi senyawa organik dan nitrogen yang sebenarnya dari lumpur aktif (RAS) dan limbah domestik yang akan diolah sehingga dapat ditentukan variasi konsentrasi yang digunakan. Dalam analisis karakteristik awal ini juga dilakukan analisis MLSS dan MLVSS untuk mengetahui konsentrasi padatan tersuspensi yang terkandung di dalam lumpur, sehingga dapat ditentukan volume lumpur yang dibutuhkan di dalam satu reaktor agar sesuai dengan kriteria desain MBBR. Hasil analisis karakteristik awal limbah dan RAS dapat dilihat pada Tabel. 1. 
Tabel. 1

Hasil analisis karakteristik awal limbah dan RAS

\begin{tabular}{cccc}
\hline \hline No & Parameter & Satuan & Nilai \\
\hline 1 & COD inlet & $\mathrm{mg} / \mathrm{L}$ & 454 \\
2 & COD outlet & $\mathrm{mg} / \mathrm{L}$ & 246 \\
3 & Amonium & $\mathrm{mg} / \mathrm{L}$ & 64.7 \\
4 & Nitrat & $\mathrm{mg} / \mathrm{L}$ & 11.2 \\
5 & $\mathrm{pH}$ & - & $7,41-7.56$ \\
6 & Salinitas & $\mathrm{ppt}$ & $0,38-0.39$ \\
7 & MLSS & $\mathrm{mg} / \mathrm{L}$ & 17.740 \\
8 & MLVSS & $\mathrm{mg} / \mathrm{L}$ & 16.680 \\
9 & TKN $($ low $)$ & $\mathrm{mg} / \mathrm{L}$ & 102 \\
10 & TKN $($ high $)$ & $\mathrm{mg} / \mathrm{L}$ & 133 \\
\hline \hline
\end{tabular}

\section{B. Penurunan Senyawa Nitrogen}

Penyisihan nitrogen terjadi pada proses aerobik maupun anoksik. Proses yang terjadi pada fase aerobik adalah nitrifikasi sedangkan proses yang terjadi pada saat anoksik adalah denitrifikasi. Pada reaktor dengan waktu durasi pengolahan aerobik 31,5 jam menunjukan hasil efisiensi ammonium-nitrogen yang paling tinggi. Hal ini diindikasikan bahwa proses nitrifikasi berjalan baik dikarenakan ketersediaan oksigen terlarut yang mencukupi untuk bakteri Nitrosomonas dan Nitrobacter dalam mendegradasi senyawa nitrogen. Reaksi biokimia proses nitrifikasi adalah sebagai berikut:

$$
\begin{aligned}
& \mathrm{NH}_{4+}+1,5 \mathrm{O}_{2} \cdot \mathrm{NO}_{2-}+\mathrm{H}_{2} \mathrm{O}+2 \mathrm{H}_{+}+\text {energy } \\
& \mathrm{NO}_{2-}+0,5 \mathrm{O}_{2} \cdot \quad \mathrm{NO}_{3-}+\text { energy } \\
& \mathrm{NH}_{4+}+2 \mathrm{O}_{2} \cdot \quad \mathrm{NO}_{3-}+2 \mathrm{H}_{+}+\mathrm{H}_{2} \mathrm{O}
\end{aligned}
$$

Parameter ammonium-nitrogen diproduksi dengan cara mendegradasi senyawa nitrogen secara biologis. Keberadaan amonium pada proses anoksik/ anaerobik juga menjadi salah satu indikator terjadinya aktivitas mikroorganisme terutama pada proses degradasi senyawa protein. Pada kondisi kurang oksigen proses nitrifikasi akan mengalami gangguan sehingga amonium-nitrogen yang terkandung pada limbah tidak terolah namun justru mengalami peningkatan. Konsenrasi amonium dapat meningkat sejalan dengan kenaikan $\mathrm{pH}$ dan temperatur [8]. Hal lain yang mendukung berlangsungnya nitrifikasi adalah kandungan DO di dalam air limbah. Pernyataan tersebut mendukung hasil analisis pada masing - masing durasi waktu pengolahan. Terlihat bahwa setiap hasil analisis pada fase anoksik nilai ammonium naik dari fase sebelumnya. Namun, pada reaktor dengan durasi proses aerobik 22,5 jan dan anoksik 22,5 jam terlihat bahwa pada fase anoksik tiga terjadi penurunan pada konsentrasi ammonium. Hal ini di indikasikan terjadi karena kandungan oksigen terikat pada fase tersebut masa tersedia dalam jumlah banyak sehingga memungkinkan terjadinya proses nitrifikasi.

Penurunan nilai ammonium yang paling optimum terjadi pada reaktor dengan durasi pengolahan aerobik 31,5 jam dan anoksik 13,5 jam. Penurunan terbaik terjadi pada reaktor dengan konsentrasi COD low dan konsentrasi COD high. Hal ini disebabkan proses nitrifikasi yang terjadi pada reaktor tersebut berlangsung baik dikarenakan durasi aerobik yang lebih lama sehingga mendukung terjadinya proses nitrifikasi. Proses nitrifikasi yaitu pengubahan amonium menjadi nitrat dengan melibatkan mikroorganisme dalam kondisi aerobik. Bentuk reaksi total oksidasi yang terjadi pada proses aerobik adalah sebagai berikut:

$$
\mathrm{NH}_{4}^{+}+2 \mathrm{O}_{2} \rightarrow \mathrm{NO}_{3}^{-}+2 \mathrm{H}^{+}+\mathrm{H}_{2} \mathrm{O}
$$

Proses nitrikasi dapat berlangsung secara optimum dalam kondisi aerobik pada kandungan oksigen terlarut $>2 \mathrm{mg} / \mathrm{L}$ dan pada kondisi pH berkisar antara 7,0 hingga 8,3 [9]. Pada reaktor dengan durasi pengolahan aerobik selama 31,5 jamanoksik 31,5 jam dapat dilihat bahwa nilai $\mathrm{pH}$ selalu mengalami kenaikan pada fase aerobik dan nilai DO yang cukup untuk terjadinya proses nitrifikasi yaitu 3,82 ppm untuk konsentrasi COD low dan 3,85 ppm untuk konsentrasi COD high. Penyisihan ammonium - nitrogen pada masingmasing durasi pengolahan dapat dilihat pada Gambar 3, Gambar 4 dan Gambar 5.

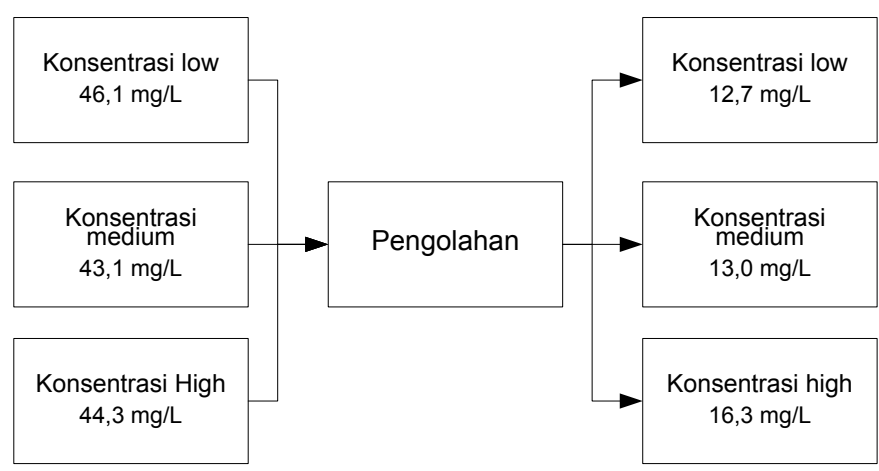

Gambar 3 Removal total ammonium pada durasi pengolahan 13,5 jam aerobik-31,5 jam anoksik

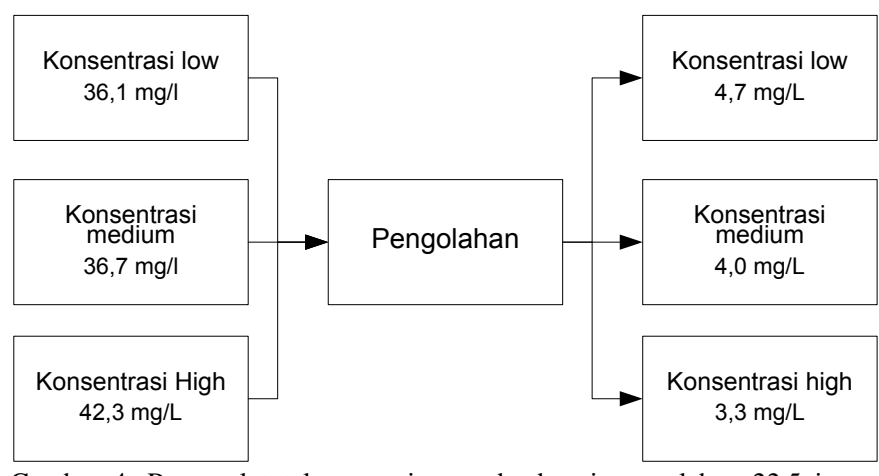

Gambar 4. Removal total ammonium pada durasi pengolahan 22,5 jam aerobik-22,5 jam anoksik.

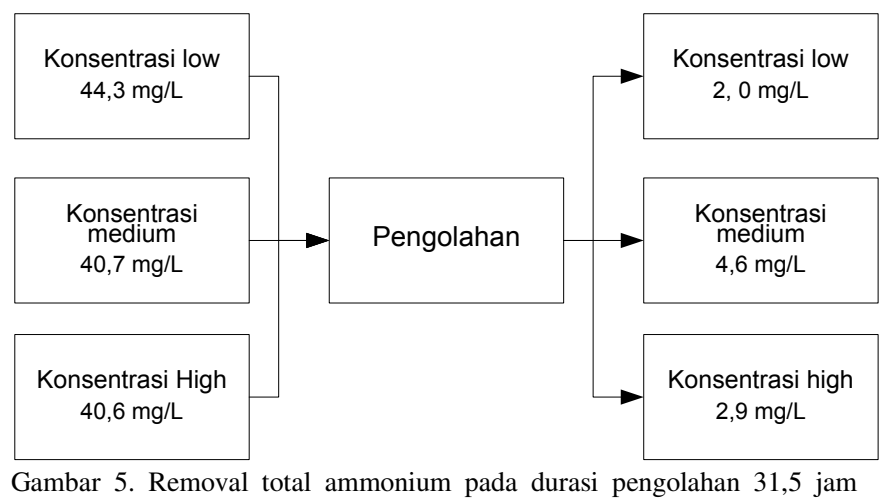
aerobik-13,5 jam anoksik.

Pada reaktor - reaktor dengan durasi pengolahan aerobik lebih lama menunjukan efisien removal yang semakin besar. Hal ini berbanding lurus dengan ketersediaan oksigen yang mencukupi sehingga bakteri Nitrosomonas dan Nitrobacter 
dapat mendegrasi dengan baik. Kemudian hasil perubahan ammonium yang telah menjadi nitrat - nitrogen akan dikonversi menjadi $\mathrm{N}_{2}$ gas yang dilepas ke atmosfer melalui proses denitrifikasi. Denitrifikasi biologis yang terjadi di dalam reaktor yaitu dengan mengaplikasikan jenis proses denitrifikasi berupa postanoxic denitrification. Proses aerobik dilakukan di awal kemudian dilanjutkan dengan proses anoksik. Kondisi aerobik dilakukan untuk mempersiapkan kecukupan oksigen terikat yang dibutuhkan pada proses anoksik. Ketika postanoxic denitrification memiliki laju reaksi yang lebih lambat dibandingkan dengan preanoxic denitrification. Hal ini dikarenakan proses denitrifikasi yang hanya bergantung pada respirasi endogeneous untuk mendapatkan energi [4]. Hasil analisis nitrat-nitrogen selanjutnya dapat dilihat pada Gambar 6; Gambar 7 dan Gambar 8.

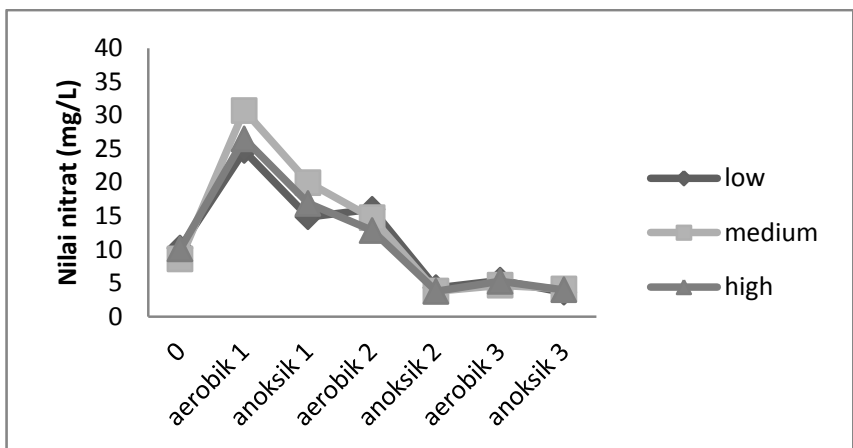

Gambar 6. Hasil Analisis Nitrat dengan durasi waktu aerobik 13,5 jam dan anoksik 31,5 jam.

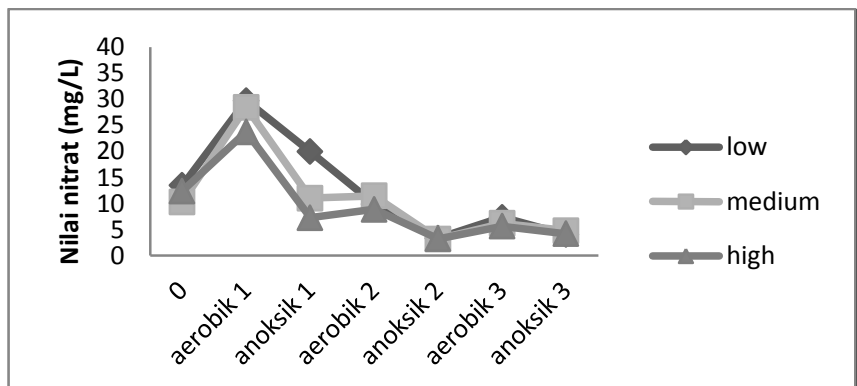

Gambar 7. Hasil Analisis Nitrat dengan durasi waktu aerobik 22,5 jam dan anoksik 22,5 jam.

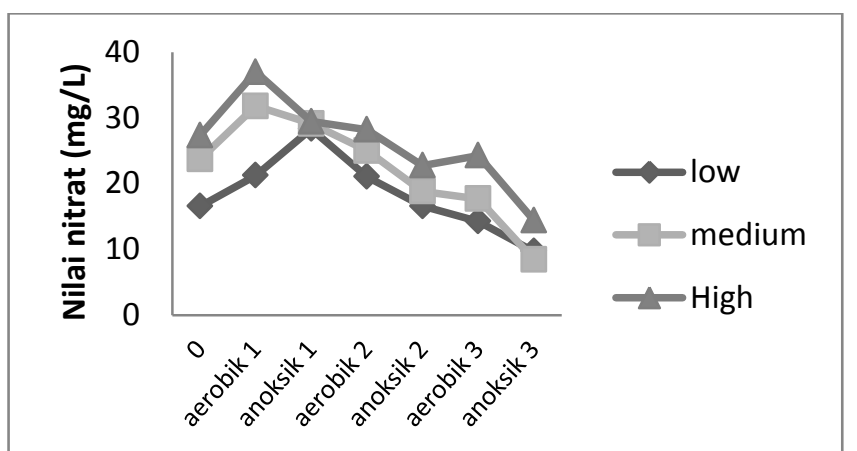

Gambar 8. Hasil Analisis Nitrat dengan durasi waktu aerobik 31,5 jam dan anoksik 13,5 jam.

Berbading terbalik dengan hasil analisis ammoniumnitrogen bahwa dengan semakin banyaknya jumlah ketersediaan oksigen maka semakin baik juga removal yang dicapai. Pada nitrat dapat dilihat bahwa pada proses pengolahan dengan waktu aerasi lebih sebentar akan menghasilkan efisiensi removal yang semakin baik. Penurunan nitrat-nitrogen terbaik terjadi pada

\section{Analisis Biomassa sebagai MLSS}

Mixed-Liquor Suspended Solid (MLSS) merupakan jumlah total dari padatan tersuspensi yang berupa material organik dan mineral termasuk di dalamnya mikroorganisme. Sedangkan MLVSS merupakan material organik mikroba, baim mikroba hidup maupun mikroba mati dan hancuran sel. Pengukuran MLSS ini dilakukan untuk memastikan bahwa reaktor telah berjalan sesuai dengan kriteria desain. Selain itu, pengukuran biomassa dengan jumlah MLVSS juga dilakukan untuk mengetahui besar perbandingan jumlah substrat dengan nikroorganisme yang tersedia (rasio F/M) di dalam reaktor. Selama berjalannya penelitian MLSS akan meningkat karena adanya pertumbuhan dan perkembangbiakan dari mikroorganisme di dalam reaktor. Semakin banyak MLSS yang digunakan dalam sistem pengolahan mengindikasikan bahwa terdapat lebih banyak mikroorganisme pengurai dalam sistem tersebut sehingga aktivitas penguraian bahan organik dan nitrogen yang terkandung dalam limbah lebih cepat [10]. Namun, selama berlangsungnya penelitian terlihat bahwa pada kondisi aerobik yang lebih lama akan menghasilkan jumlah biomassa yang lebih banyak. Hasil analisis MLSS dapat dilihat pada Gambar 9, Gambar 10 dan Gambar 11.

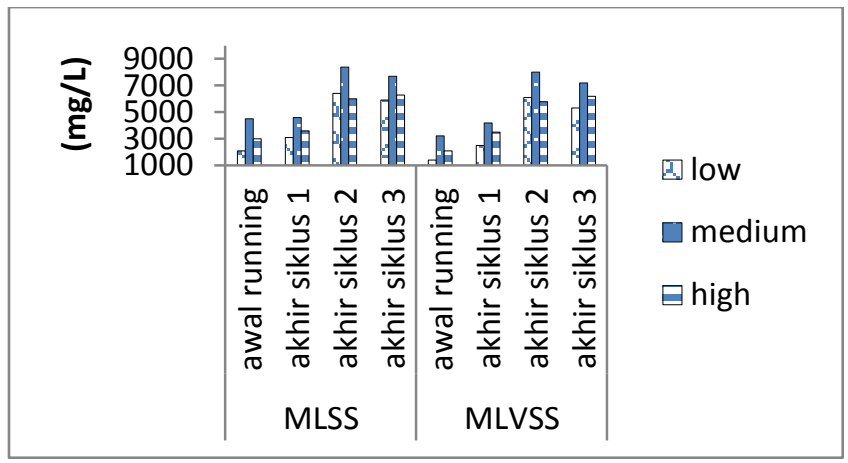

Gambar 9. Hasil Analisis MLSS pada durasi waktu aerobik 13,5 jam dan anoksik 31,5 jam

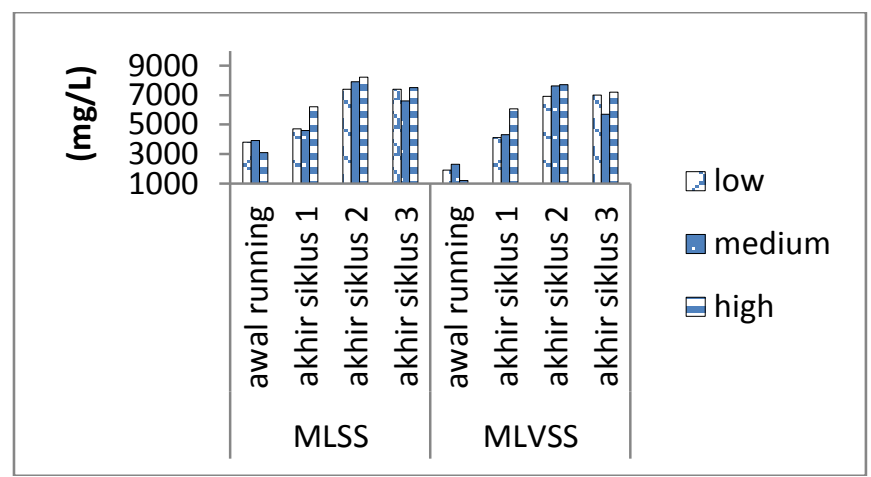

Gambar 10. Hasil Analisis MLSS pada durasi waktu aerobik 22,5 jam dan anoksik 22,5 jam. 


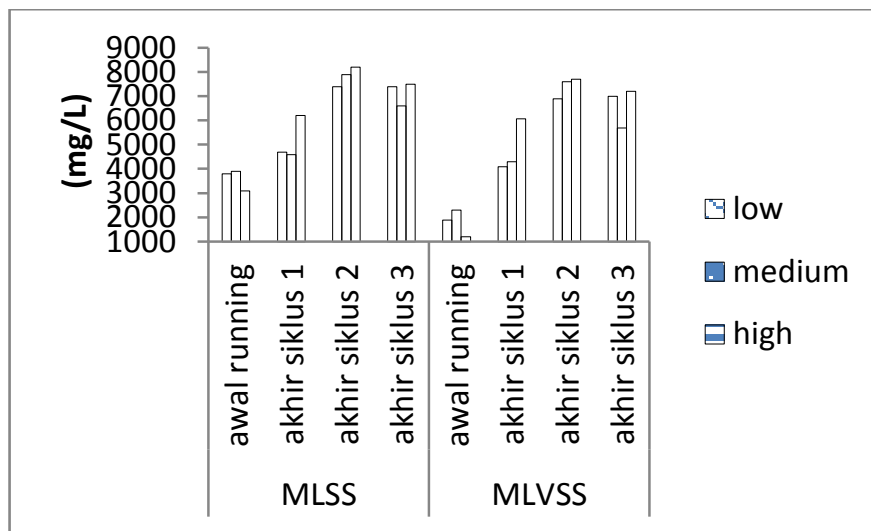

Gambar 11. Hasil Analisis MLSS pada durasi waktu aerobik 31,5 jam dan anoksik 13,5 jam.

D. Analisis $p H$

Selain jumlah biomassa dan Dissolved Oxygen, parameter lain yang berpengaruh terhadap proses nitrifikasi dan denitrifikasi yang terjadi adalah $\mathrm{pH}$. Nilai $\mathrm{pH}$ disetiap reaktor selama kegiatan running berlangsung yaitu berkisar antara 6.76 - 8.25. Pada masing - masing reaktor uji terjadi fluktuasi nilai $\mathrm{pH}$. Nilai Kenaikan nilai $\mathrm{pH}$ ini dapat diakibatkan dari perubahan bentuk ammonia-nitrogen menjadi bentuk ion yang berupa ammonium jika terlarut di dalam air. Sehingga ion $\mathrm{OH}^{-}$di dalam limbah akan menjadi naik yang berdampak pada naiknya nilai $\mathrm{pH}$ sebagaimana reaksi berikut:

$\mathrm{NH}_{3}+\mathrm{H}_{2} \mathrm{O} \longleftrightarrow \mathrm{NH}_{4}^{+}+\mathrm{OH}^{-}$

Selain itu, nilai $\mathrm{pH}$ di dalam reaktor juga dapat mengalami penurunan jika terjadi proses pembentukan nitrat (Sawyer et al., 2003), dengan reaksi:

$\mathrm{NH}_{4}^{+}+3 / 2 \mathrm{O}_{2}$

$$
\longrightarrow \mathrm{NO}_{2}^{-}+2 \mathrm{H}^{+}+\mathrm{H}_{2} \mathrm{O}
$$

$\mathrm{NO}_{2}^{-}+1 / 2 \mathrm{O}_{2}$ $\mathrm{NO}_{3}^{-}$

Reaksi di atas menunjukkan bahwa setiap mol ammonium yang dioksidasi akan memproduksi 2 mol ion hidrogen, yang hasilnya akan menurunkan nilai $\mathrm{pH}$ pada lingkungan yang nilai buffernya rendah [11]. Hal ini menunjukkan bahwa bakteri autotrofik yang ada pada proses nitrifikasi sangat sensitif terhadap nilai $\mathrm{pH}$. Akan tetapi, kenaikan dan penurunan nilai $\mathrm{pH}$ pada semua variasi konsentrasi limbah tidak signifikan, nilainya relatif hampir sama dan masih berada pada kisaran nilai $\mathrm{pH}$ netral. Pengukuran nilai $\mathrm{pH}$ dari masing - masing reaktor dapat dilihat pada Gambar 12; Gambar 13 dan Gambar 14.

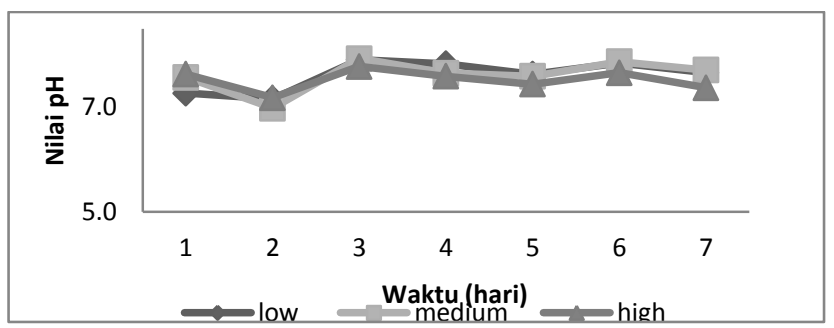

Gambar 12. Hasil Analisis pH pada durasi waktu aerobik 13,5 jam dan anoksik 31,5 jam.

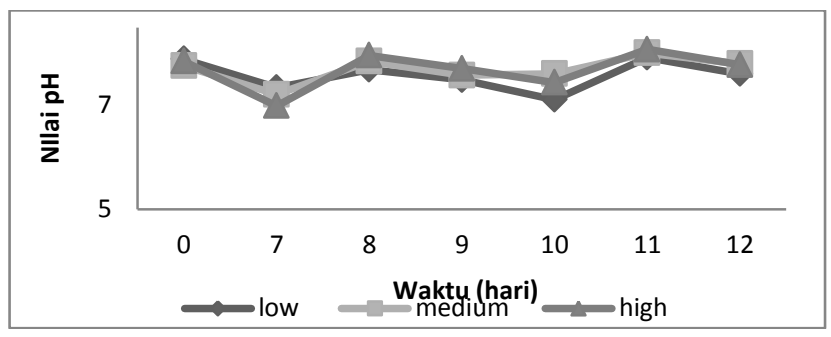

Gambar 13. Hasil Analisis pH pada durasi waktu aerobik 22,5 jam dan anoksik 22,5 jam.

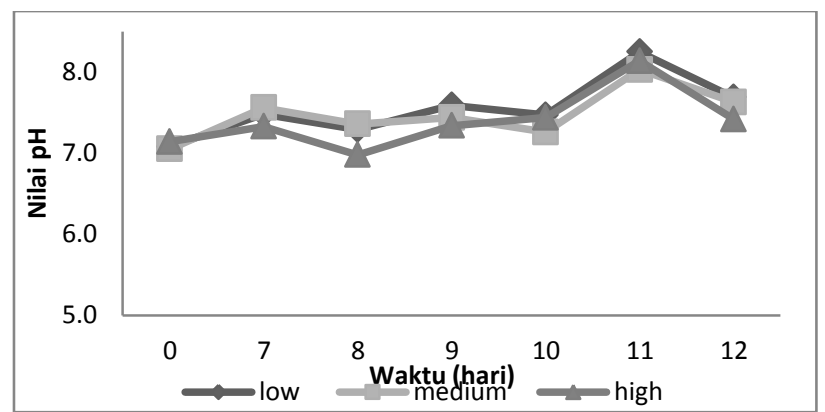

Gambar 14. Hasil Analisis $\mathrm{pH}$ pada durasi waktu aerobik 31,5 jam dan anoksik 13,5 jam.

Nilai $\mathrm{pH}$ di dalam setiap reaktor masih termasuk ke dalam rentang $\mathrm{pH}$ yang baik untuk pertumbuhan dan perkembangbiakan bakteri. Nilai $\mathrm{pH}$ tersebut yaitu 6,5-7,5 dan berada pada suhu $25^{\circ} \mathrm{C}-35^{\circ} \mathrm{C}$. Nilai $\mathrm{pH}$ optimum untuk proses nitrifikasi berkisar antara $\mathrm{pH} 7-8$, apabila $\mathrm{pH}$ berada kurang dari 6,5 maka tidak akan terjadi pertumbuhan bakteri autotrofik (bakteri nitrifikasi) [11]. Pada penelitian ini nilai $\mathrm{pH}$ yang ditunjukkan oleh reaktor MBBR outlet menunjukan rentang $\mathrm{pH}$ optimum yaitu sebesar 7,5 - 8.25 yang termasuk pada rentang $\mathrm{pH}$ optimum proses nitrifikasi sehingga memiliki besar efisiensi removal ammonia-nitrogen yang baik. Hal ini menunjukkan mikroorganisme yang berkembang dengan baik adalah bakteri nitrifikasi (autotrofik) atau mikroorganisme aerobik obligat [4]. Pada penelitian ini nilai $\mathrm{pH}$ yang ditunjukan pada reaktor dengan durasi pengolahan aerobik 31,5 jam- anoksik 13,5 jam menunjukan $\mathrm{pH}$ optimum untuk proses nitrifikasi sehingga memiliki besar efisiensi removal ammonium-nitrogen paling baik. Hal ini menunjukan mikroorganisme yang berkembang dengan baik adalah bakteri nitrifikasi (autototrofik) atau mikroorganisme aerobik obligat [4].

\section{KESIMPULAN}

Moving Bed Biofilm Reactor (MBBR) dengan media kaldness (K1) mampu mengolah limbah domestik dengan menurunkan kandungan anomium-nitrogen adalah sebesar $92,8 \%$, nitrat-nitrogen sebesar $66,4 \%$, nitrit-nitrogen sebesar $99,7 \%$ dan total nitrogen sebesar $67,4 \%$. Sedangkan waktu durasi pengolahan yang paling optimum adalah dengan lama durasi pengolahan aerobik selama 31,5 jam dan anoksik selama 13,5 jam. Pada waktu durasi pengolahan tersebut menghasilkan efisiensi penurunan nitrogen yang paling baik.

\section{DAFTAR PUSTAKA}

A. Sastrawijaya, Pencemaran Lingkungan. Jakarta: PT. Rineka Cipta, 2009.

H. Effendi, Telaah Kualitas Air bagi Pengolahan Sumber Daya dan Lingkungan Perairan. Yogyakarta: Kanisius, 2003.

S. Luostarinen, S. Luste, L. Valentin, and J. Rintala, "Nitrogen Removal From On-site Anaerobic Effluents Using Intermittenly Aerated Moving Bed Biofilm Reactors at Low Temperatures," Water Res., pp. 1607 - 1615, 2006.

Metcalf and Eddy, Wastewater Engineering: Treatment, Disposal and Reuse, 4th ed. New York: Mc Graw Hill Book Co., 2003.

M. Kemani, B. Bina, H. Movalhedian, and M. Amin, "Biological phosphorus and nitrogen removal from wastewater using moving bed biofilm process," Irian J. Biotechnol., vol. 7, no. 1, pp. 1927, 2009.

F. Qaderi, B. Ayati, and H. Ganjidous, "Role of Moving Bed Biofilm Reactor and Squencing Batch Reactor in Biological 
Degradation of Formaldehyde Wastewater," J. Environ. Heal. Sci., vol. 8, pp. 295-306, 2011.

[7] M. Romli, Suprihatin, and D. Sulinda, "Penentuan Nilai Parameter Kinetika Lumpur Aktif untuk Pengolahan Air Lindi Sampah (LeacheteI)," J. Tek. Ind. Pertan., vol. 14, pp. 56-66, 2004.

[8] A. Herlambang and R. Marsidi, "Proses Denitrifikasi dengan sistem Biofilter untuk pengolahan air limbah yang mengandung nitrat," J. Teknol. Lingkung., vol. 4, no. 1, p. 46, 2003.

[9] C. N. Sawyer, P. L. McCarty, and G. F. Parkin, Chemistry for
Environmental Engineering and Science, 5th ed. Singapore: Mc Graw Hill, 2003.

[10] D. Agustiyani and H. Imamuddin, "Pertumbuhan Kultur Nitrifikasi Campuran Pada Senyawa Amonium," in Proseding Seminar Nasional Biologi XVI dan Kongres Nasional Perhimpunan Biologi Indonesia (PBI) XII, 2000.

[11] S. Tarre and M. Green, "High-Rate Nitrification at Low $\mathrm{pH}$ in Suspenden and Attached-Biomass Reactors," Appl. Environ. Microbiol., vol. 70, pp. 6481-6487, 2004. 